\title{
Analysis of Pakistan Trade Policies in the Context of Export Diversification
}

\author{
Aamir Hussain Siddiqui*
}

\begin{abstract}
This paper attempted to analyze Pakistan export policy towards diversification. There are five measures of export diversification which is widely used by scholars for such analysis. The computational analysis reveals that export diversification always remains the major policy goal of Pakistan's trade policies since the decade of 1970s. However, the outcome of the policy could not be successful because export diversification indexes showed no significant changes. From the year 2000 government focuses on geographical export diversification and concentrated on preferential trade agreements, which could not show good result as well. This paper therefore suggests for commodity export diversification, preferably vertical diversification for a sustainable export growth of the country.
\end{abstract}

Keywords: Export diversification, Trade policy, Herfindahl-Hirschman Index, Export experience function, Economic growth.

\section{Introduction}

Economic progress and development is the agenda of every economic management or policy makers. Rostow says that it is achieved gradually. He gave 7-stages of development which starts from traditional agrarian society to industrialization and culminates in mass consumption. This transformation is one of the important determinants of development, which is due to existence of elastic demand for a country's export in the international markets. Hesse et al. (2009) stated that many developing countries export growth is one of the major channels of long run economic growth as their domestic demand growth remains very low. Many developing countries which are export dependent upon a few commodities are likely to suffer from export instability. This situation can be countered through export diversification. Hesse et al. (2009) further argued that the process of globalization has increased competition in international markets, therefore competitiveness is become a prominent issue of the developing countries.

The International data on export diversification showed Pakistan among those low income developing countries (see table-1) which export concentration remains relatively high and has increased during 2012-15. The index in the table is concentration index, so the lower value indicates higher level of diversification. According to the table Turkey has the highest level of product export diversification level, followed by Thailand, China and India. India was showing high concentration till 2012 and then concentration fall

\footnotetext{
*Assistant Professor / Research Economist, Applied Economics Research Centre, University of Karachi, Pakistan.

Email: aamir.siddiqui@aerc.edu.pk
} 
significantly, Concentration Index value falling by 30 percent. Overall we can say there is no noticeable significant changing in level of diversification over the 10 -year period in the case of Pakistan.

\begin{tabular}{lcccc}
$\begin{array}{l}\text { Table 1 } \\
\text { Concentration Index (HHI) of exports of selected developing countries } \\
\text { (low values of index shows more diversification) }\end{array}$ \\
\hline YEAR & $\mathbf{2 0 0 6}$ & $\mathbf{2 0 0 9}$ & $\mathbf{2 0 1 2}$ & $\mathbf{2 0 1 5}$ \\
\hline Turkey & 0.090519 & 0.083099 & 0.092117 & 0.073415 \\
Thailand & 0.092717 & 0.086892 & 0.081955 & 0.076544 \\
China & 0.109621 & 0.108690 & 0.101495 & 0.104248 \\
India & 0.140052 & 0.148553 & 0.172561 & 0.119711 \\
Brazil & 0.090033 & 0.117465 & 0.146450 & 0.128103 \\
Indonesia & 0.128695 & 0.151793 & 0.169772 & 0.137357 \\
Nepal & 0.132031 & 0.140759 & 0.141863 & 0.137493 \\
Egypt & 0.253659 & 0.150844 & 0.171900 & 0.140019 \\
Korea, Republic of & 0.155257 & 0.160926 & 0.146779 & 0.147738 \\
Viet Nam & 0.208042 & 0.130216 & 0.137024 & 0.159280 \\
Malaysia & 0.182205 & 0.174087 & 0.163973 & 0.169554 \\
Pakistan & 0.227747 & 0.201971 & 0.182851 & 0.202381 \\
Sri Lanka & 0.204072 & 0.225250 & 0.203184 & 0.203687 \\
Cambodia & 0.374652 & 0.335442 & 0.296480 & 0.311969 \\
Bangladesh & 0.387455 & 0.415625 & 0.396830 & 0.400950 \\
\hline Source: UNCTAD & & & &
\end{tabular}

This paper is an attempt to conduct a descriptive analysis (a subjective but value based analysis) for Pakistan's trade policies between 1972 to 2015. For this purpose, we will use 5 different types of diversification indexes and Pakistan's trade policies.

\section{Pakistan Trade Policies for Export Diversification}

We start our analysis with trade policies of the 1970s. Devaluation of the currency was the major trade policy tool used for enhancement of exports. There was no explicit export diversification policy initiative throughout this decade. However, due to the foreign policy of closer ties with Islamic countries, Pakistan increased its exports to the Middle Eastern markets. Therefore, we can say that there was some geographical export diversification during that decade.

We have analyzed the notifications issued by the Ministry of Commerce, in respect of trade policies of Pakistan during the 1980s, which were in fact export and import control orders. All the policy measures were stereotyped explaining Pakistan's export policy formulated on the basis of pillars, which include both product and market diversification. The policy of export promotion was built on grant of export rebate and other financial concessions. Usually concessions were given to the then existing and relatively established manufacturing sectors. This implies that there was no clear cut policy of export diversification. In fact, the policies were strongly focused on import substitution. Since the policy statements do not show as to which policy measure is taken specifically for export diversification therefore it may be implied that there was no policy to encourage export diversification.

For example, the notifications for trade policies during 1986 to 1990 included exports rebate and export financing at concessional rates as major policy instruments for 
export promotion. Export rebates were available for 19 major export items, including, cotton yarn, cotton cloth, made-ups, synthetic and woolen yarn, carpets, canvas footwear, threads, engineering goods, surgical goods, leather goods, Rexene and plastic watercoolers. Before 1986 the export rebate was paid equivalent to $12.5 \%$ of the exports value. However gradually it was reduced or withdrawn. According to the 1987 trade policy the rebate was withdrawn from cotton yarn, grey cloth threads and woolen yarn. Rebate on fiber glass and PVC products, engineering goods, surgical items, wooden launches and plastic water-cooler remained unchanged. Overall rebate was reduced by $5 \%$ points for rest of the 13 products out of 19 products. Export finance was available to all commodities except 25 commodities/sectors, which included cotton and cotton yarn, fish, meat, vegetables, leather, food sector, chemicals, metal products and wood products, etc. These were the industries/commodities which were non-traditional. The rebate support for two product group engineering goods and plastic water-coolers can be considered as the product export diversification.

The other policy instrument used was the administration of the export quota for the Multi-Fiber Arrangement (MFA) of the various importing countries and regions (including, USA, Canada, the European Economic Community, Finland and Sweden). The MFA 1982-86 was administered purely by the government, for the period 1987-1991 textiles associations were given the task of quota administration. Here maximum possible earning of foreign exchange was the basic objective in the allocation of textile quota. Government also used to decide participation in selected fairs and exhibitions. Usually 20 to 25 international exhibitions and 5 to 10 trade delegations annually were planned for export promotion purpose. This may be regarded as an incentive for geographical export diversification, as only those products were selected for exhibitions which are already produced, therefore visits of trade delegation and participation in exhibition is only a kind of exploring new markets.

There were some other export expansion measures through capacity building of increasing market access or geographical diversification. There was various program undertaken with the assistance of the European Union, UNCTAD and JETRO (Japan External Trade Organization) for providing training on export market research and compliance of market access requirement for Europe and other developed countries. However, these programs were only for government officials and therefore not result oriented.

The trade policies of the 1990s verbally recognized the need for export diversification, but the main concern remained liberalization of trade. This decade is known as the decade of structural adjustment programs and after completion of the first program in 1993, government announced trade reforms, the main features of which were as follows:

1. Only six custom duty slabs were initiated.

2. Maximum duty was set at $35 \%$ and in some special cases at $50 \%$

3. Duty free import of raw material used for the production of export goods was allowed.

4. Duty on import of machinery not manufactured locally was set at $10 \%$. 
5. All para-tariffs, such as import license fee, Iqra surcharge and flood relief surcharge were merged into the import tariff.

All above measured showed that government has taken steps for liberalization of import regime and no product or geographical export diversification initiatives were taken.

The trade policy for 2001-02 again focused on five pillars, one of which was diversification of the export base. The policy document and speech of the Commerce Minister acknowledged the failure in achieving the goal of export diversification during the past periods. However, the policy emphasized a demand led strategy which sought to increase market share in three major products - textiles, leathers and rice - which then constituted $90 \%$ of total export earnings. This is contrary to the objective of export diversification. For geographical export diversification it was planned to tap the opportunities in Africa, China, South America and Eastern Europe. For this purpose, the Export Promotion Bureau prepared special plan to organize fairs and exhibitions and sent various trade delegations to these regions.

The trade policy for 2005-06 and 2006-07, had the same objectives of product and market diversification. This time, more focus was given to geographical export diversification and Pakistan signed various bi-lateral preferential and free trade agreements with some regional partners such as China, Sri Lanka, Malaysia, Mauritius and Iran. In addition to that multilateral trade agreements were also signed with the context of the South Asian Free Trade Area (SAFTA), Economic Cooperation Organization Trade Agreement (ECOTA) and Developing Eight (D-8) countries. Pakistan was given duty free market access under the European Union's "Drug GSP " scheme to the garment sector in 2004-05. This special preference was given due to our joining of the international coalition for war in Afghanistan. However, this could be continued for three years only, when WTO gave a decision against this preference. One of the very important developments in international markets was that MFA was completely abolished by the European Union on 31 December 2004 and only tariff barriers remained on the import of textile and garments. To support the export of value added garment export to the European Union markets, government had announced 6\% (of the total fob export value) as Research \& Development support on export to EU. These policies were purportedly against the objective of product and geographical export diversification. Because garments were the only sector and Europe was the only region where export was supported.

From 2009, onwards the government has been announcing the trade policies for three years, which are called Strategic Trade Policy Framework (STPF). The first STPF was announced for the 2009-12 period. Export diversification was one of the core objectives of STPF 2009-12. Duty drawback rates were increased by $1 \%$ on non-traditional development sectors. Regional trade especially with Central Asian Republics and Gulf countries was encouraged. Again more emphasis was given to geographical export diversification and plans were prepared to exploit the opportunities in China, USA, EU, Malaysia and Sri Lanka. Following were the specific measures announced for promotion of exports:

1. Inland freight subsidy on export of cement, chemicals, fish, marble granite, light engineering products, furniture and leather products.

2. Support for technology up-gradation for export of value added products. 
3. Support for brand promotion of surgical instruments,

4. Support for marketing of light engineering products.

5. Support to meet Technical Barriers to Trade (TBT) on processed food exports.

6. Matching grants to leather garment exporters for designing and innovation.

7. Support for Halal certification.

The subsidies were offered to very few non-traditional export items, which implies that product diversification was not encouraged.

The second STPF 2012-15 had the same objectives and principle elements including both product and market diversification. Overall an amount of US\$275 million was approved for the entire STPF. Relief in capital expenditure and export financing was given to some non-traditional sectors including, leather, fish, sports goods, cutlery, electrical fans and surgical goods etc., under the new policy. Under this policy support was available on payment of mark-up only. The policy again focused on the trade expansion with regional countries, such as India, China, Afghanistan and Iran. These are market diversification related measures, which was continued for this period. The policy measures focused on skill development and government had allocated resources for the institutes of skill development of export sectors. The policy measures did not seem to encourage export diversification. It is important to note that Government had set a cumulative export target of US\$ 95 billion for 2012-15 period, while the allocated amount of 0.275 billion was $0.3 \%$ of the export target. This amount was not sufficient for achieve the target and export results shows that the various target including export diversification could not be achieved.

The STPF 2015-18 once again emphasizes product and market diversification. This time incentives were announced to the firms for investment in export related activities and products. Priority was given to SMEs located in low income economic district of Pakistan such as, Khyber Pakhtoonkhaw, Gilgit, Baluchistan and Federal Tribal Areas with regard to mineral and agricultural products. The policy aimed for transition from 'factor driven' to an 'efficiency' and 'innovation driven' export regime. These terms were taken from the Global Competitiveness Reports, where countries are classified in these three stages of development level. The STPF has allocated approximately US\$ 58 million for implementation of trade policy initiatives during 3 years. Special focus was given to the non-traditional sectors, which includes leather, pharmaceutical, fisheries, surgical instruments, sport goods, and cutlery. The incentives include financial support upto $50 \%$ on importation of modern technology for up-gradation of product quality and competitiveness and $50 \%$ on mark-up support for financing the export projects of the above mentioned sectors. The policy statement also announced that SME would be given priority. For greater market access, or in other words market diversification, negotiation for trade agreement with Korea, Jordan, Kazakhstan was also initiated. Incentives was again available to same few non-traditional products and same emphasis on the regional trade which has never worked. Such policy measures again do not seem encouraging for export diversification. 


\section{Literature Review}

There is a generous literature (theoretical and empirical) on the impact of export diversification on growth. Focus on product specialization for economic development has strong historical roots. To the best of our knowledge Ibn-e-Khaldun (AD 1332-1406) was the first scholar to develop a narrative on the specialization theme. He had clearly referred to the advantages of diversion of labours among individuals; implications can be drawn about its advantage with regard to production and trade among countries.

Adam Smith developed almost the same narrative and formulated the theory of $\mathrm{Ab}$ solute Advantage. According to him specialization and division of labor contribute to welfare and economic development. This theory was further extended by David Ricardo in the form of the theory of Comparative Advantage and then by Heckscher-Ohlin who introduced the idea of factor endowment and factor proportions. However, the case of diversification, has gained popularity on the basis of empirical investigations, where it is shown that developing countries can attain rapid economic development through export diversification both in terms of products and markets. International organizations, such as World Bank, WTO and UN's economic organizations have also emphasized the importance of diversification of exports for developing countries.

Hamed, Hadi, and Hossein (2014) found a positive effect of export diversification on economic growth in developing countries. They followed (Balassa, 1977) index for export diversification which computed as standard deviation of Revealed Comparative Advantage (RCA) Index. Balavac M. and Pugh G. (2016) used Herfindahl-Hirschman Index (HHI) and Theil Index for measuring export diversification and found a positive and significant relationship between output growth and export diversification. Ahmed and Hamid (2014) used the cumulative export experience function at 2 digit level of SITC export statistics of Pakistan to scrutinize the degree of traditionality and structural change of Pakistan's export industries. Their investigation showed GDP and trade openness as significant relationship with Structural Change index.

Hamid (2010) found a positive relationship of both geographical and product diversification for exports of Malaysia on export growth. They used HHI index for measuring the export diversification. Forgha, Sama, and Atangana (2014) found export diversification positively affects GDP per capita for Cameron. Granger causality test also showed the same result. The authors used HHI index for measuring the export diversification. Siddiqui (2018) estimated the effect of export diversification, both product and geographical, on economic growth for Pakistan. Author used HHI index to measure both type of diversification. The results showed a positive and significant relationship between product export diversification and economic growth, however, geographical export diversification showed an insignificant relationship with economic growth.

Almost all studies have shown a positive relationship between export diversification and economic growth. The important conclusion to be drawn from the review is the measurement of export diversification. For single country studies most of the authors have used Herfindahl-Herschman Index or Standard Deviation of Balassa index (which is called Revealed Comparative Advantage). Apart from these there are some studies, such as Persson (2013), used number of products export at most disaggregated level of trade 
classifications.

\section{Measurement of Export Diversification}

This study used UNCOMTRADE database for trade, which was accessed through World Bank's data portal WITS (World Integrated Trade Solution. The study used the data code SITC at 4-digit level for measuring the product diversification. This study selected different regions for measuring geographical export diversification. The regions are East Asia, South East Asia, South Asia, Middle East, North Africa, Sab-Saharan Africa, Europe, South America \& Carrabin, North America and Oceania region. A time series of 45 years starting from 1972 is selected as coverage period. In this section we will discuss the measurement of export diversification. As discussed earlier various authors have used different indices for measuring export diversification. Most of the indices are basically concentration or specialization indexes and inverse of the indexes are considered as diversification. Among various concentration and diversification indices, we have addressed only the following:

1. The Herfindahl-Hirschman Index of export concentration

2. Export diversification Index of UNCTAD

3. Trade Specialization: the Revealed Comparative Advantage (RCA) index

4. Export experience function for (traditionality index)

\section{The Herfindahl-Hirschman Index (HHI) of Export Concentration}

This index measures the concentration ratio and is calculated through the following formula:

$$
H H I=\sum_{i=1}^{n}\left(\frac{X_{i j}}{X_{j}}\right)^{2}
$$

Where $\mathrm{j}$ is the country (Pakistan) and i denotes commodity. So $X_{i j}$ denotes Pakistan's export of particular commodity and $X_{j}$ denotes Pakistan's total exports in a given year. This index is also used for the geographical concentration. The geographical location is already mentioned above.

Table-2 shows, the index value for HHI-P is lower while the value for HHI-G is higher. It is because of the reason that number of products is nearly 450, and on the other hand, number of geographical locations are 8 . However, if we see the trend of both indices in the following figure-1, it doesn't look very different. 
Table 2

\begin{tabular}{lcc}
\multicolumn{3}{l}{ HHI concentration index - A summary } \\
\hline Years & $\begin{array}{c}\text { HHI-P } \\
\text { (at 4 digit SITC level) }\end{array}$ & $\begin{array}{c}\text { HHI-G } \\
\text { (Geographical) }\end{array}$ \\
\hline $1972^{\prime}$ & 0.103 & 0.298 \\
$1980^{\prime}$ & 0.083 & 0.205 \\
$1990^{\prime}$ & 0.07 & 0.262 \\
$2000^{\prime}$ & 0.07 & 0.214 \\
$2005^{\prime}$ & 0.079 & 0.12 \\
$2010^{\prime}$ & 0.065 & 0.173 \\
$2015^{\prime}$ & 0.067 & 0.191 \\
Average: & 0.072 & 0.215 \\
\hline
\end{tabular}

Figure 1

Trend of HHI-G and HHI-P
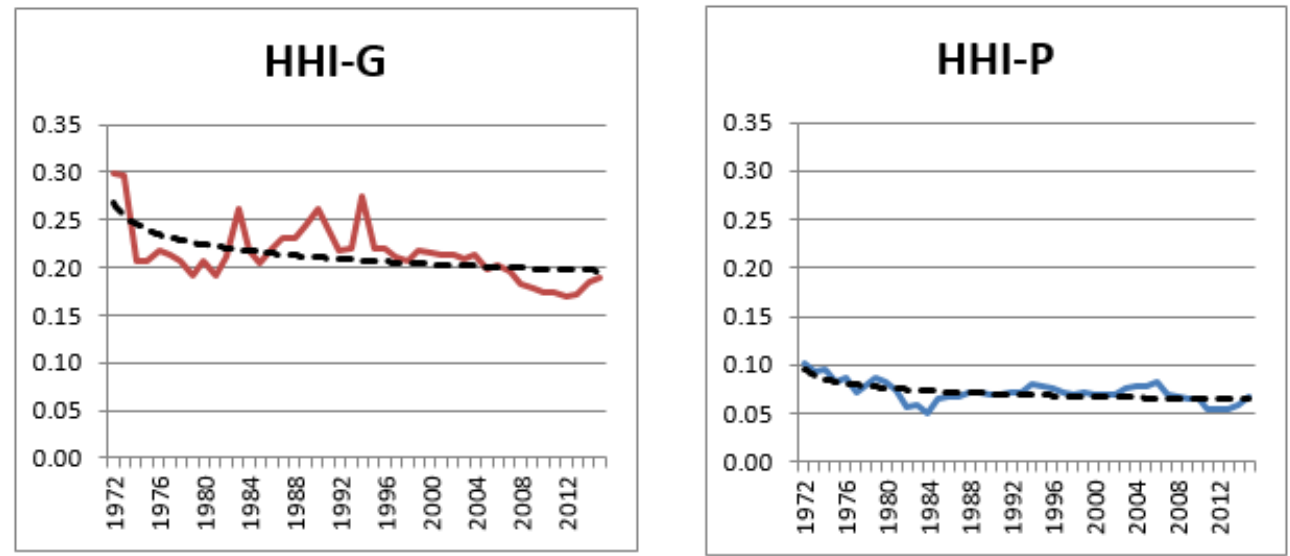

The above figure- 1 shows that Geographical diversification was lowest in 1972, as mentioned earlier that a value of $\mathrm{HHI}$ close to 1 refers low diversification. The trend also shows a unstable trend till 1995. However after this year a relatively consistent trend towards diversification is observed, but the change values are not substantial.

On the other hand, product diversification has somewhat similar trend. A consistent increase in diversification from 1972 to 1984 was observed which then a slight decrease and stable till 2007 and afterwards again a slight increase in export diversification. on a broader sight the diversification was not significant or substantial but comparatively stable than geographical export diversification.

\section{Export Diversification Index of UNCTAD}

United Nation Conference for Trade and Development (UNCTAD) has developed an index call export diversification, which is calculated through the following formula:

$$
E D_{j}=\sum_{i}\left|h_{i j}-h_{i}\right| / 2
$$


where

$E D_{j}=$ Export Diversification of Country j

$h_{i j}=$ share of product $\mathrm{i}$ in total exports or imports of country $\mathrm{j}$

$h_{i}=$ share of product $\mathrm{i}$ in total world exports or imports.

UNCTAD has developed this index from the Finger-Kreinin measure of similarity in the trade (Finger \& Kreinin, 1979). Its value ranges between 0 and 1. A value closer to zero indicates convergence to world trade patterns and values closer to 1 indicate more divergence from the world trade pattern. Therefore lower value of this index for any country would indicate relatively a diversified export pattern. This index gives the diversification indication for products only and UNCTAD database does not give the data of market diversification calculated on the basis of this index.

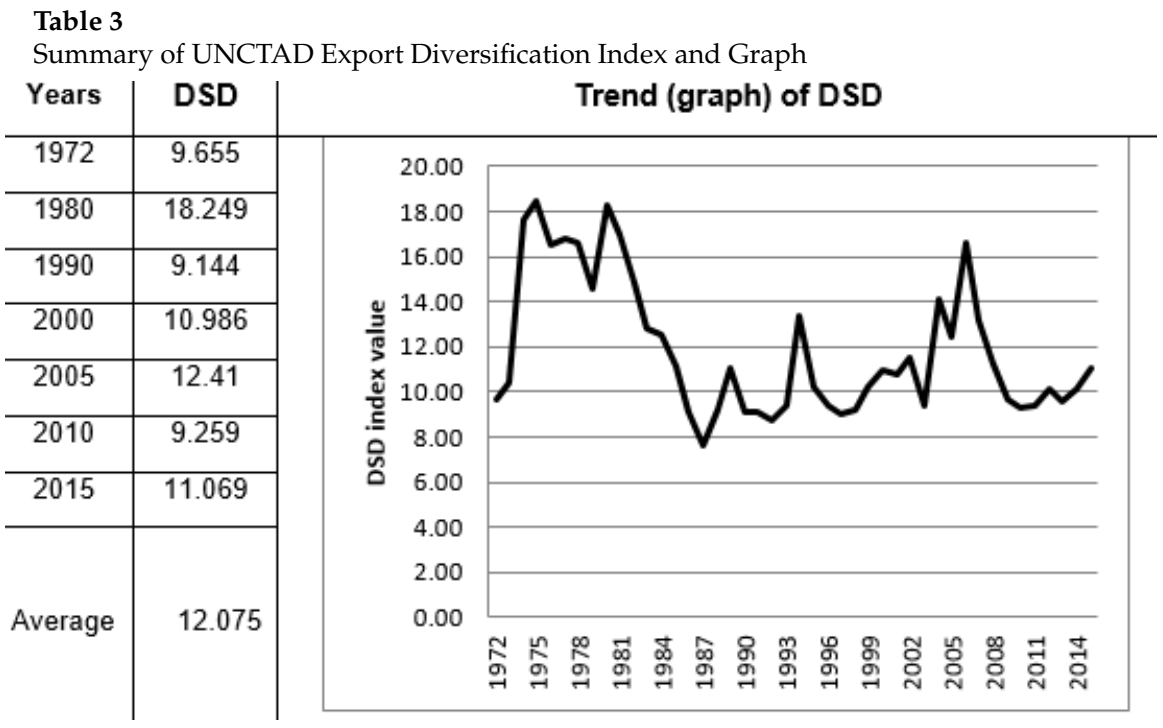

Table-3 shows summary of index value and trend of export diversification for Pakistan. Graph shows almost a straight line during the entire period of 1972 to 2015 . A small change can be visible in the later part from 2000 onward where graph shows a very right declining trend. The ED index values remain within 0.8 to 0.9 during the entire period, except in 2010, where the value is very marginally under 0.8 . The average score during this period was 0.85 , which shows a very stable value. This value shows that Pakistan's export remained very far from the world average.

According to UNCTAD data center the average ED (at 3-digit SITC level) of Developing Asia was 0.236 in 2015, while for Pakistan this score was 0.768. This value showed a larger difference of Pakistan export patter with the Asian developing nations. 


\section{Trade Specialization: The Revealed Comparative Advantage (RCA) In- dex}

Balassa (1965) developed this index, which revealed the comparative advantage of a product. The formula for calculating this index is as follows:

$$
R C A_{i j}=\left(\frac{x_{i j} / \sum_{i j}}{\sum_{j} X_{i j} / \sum_{i} \sum_{j} X_{i j}}\right)
$$

Where

$R C A_{i j}$ is the Revealed Comparative Advantage of product $\mathrm{i}$ for country $\mathrm{j}$

$x_{i j}$ is export value of product for country $\mathbf{j}$

$X_{i j}$ is total export value of country $\mathbf{j}$

$\sum_{j} X_{i j}$ is the world export of product $\mathrm{i}$

$\sum_{i} \sum_{j} X_{i j}$ is the world total exports

Balassa (1977) further argued that standard deviation of RCA would indicate degree of export diversification. A low value would indicate degree of diversification or a diversified export structure, while a higher value would indicate a more specialized export structure or degree of specialization.

$$
D S D_{t}=\sum_{i=1}^{n} \frac{\left(R C A_{i j t}-R \bar{C} A_{t}\right)^{2}}{y}
$$

Where

$D S D_{t}$ is the Export Specialization index at time period $\mathrm{t}$

$R C A_{i j t}$ is the value of Balassa index at time $\mathrm{t}$

$R \bar{C} A_{t}$ the mean value of Balassa index at time $\mathrm{t}$

$\mathrm{N}$ is the number of products at 4-digit SITC level in a time period $\mathrm{t}$

Table 4

Summary of Degree of Specialization Diversification (DSD) Index and Graph

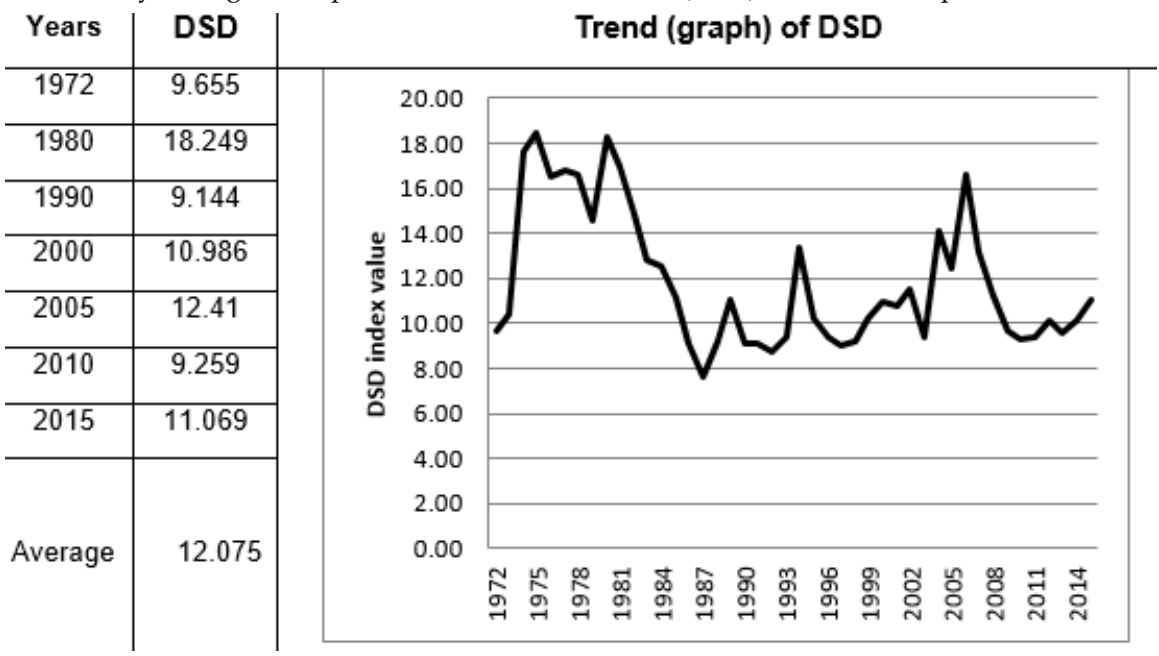


We have calculated product-wise RCA at 4-digit SITC level and have taken standard deviation of all RCAs for each year. Table- 4 shows a summary Pakistan's DSD index value and trend of DSD during the period of 1972 to 2015. According to which, most of the time, the pattern fluctuated between 10 and 15. Before 1990 there was a decreasing trend, while during 1990 to 2006 there was a mixed trend and finally from 2007 till 2015 there was downward trend.

This trend shows almost identical trend of the UNCTAD diversification trend during the period 1972 to 2015 . However, a constant trend after 1990 shows that the trade liberalization policy could not bring substantial change in the patter of export diversification in Pakistan.

\section{Export Experience Function (Traditionality Index)}

This is also a very commonly used index for analyzing industry specific export diversification. Through this index traditionality index (Akbar, Naqvi, \& Iqbal, 2001; Ahmed \& Hamid, 2014) also analyzed structural change of industry specific exports. Export experience function basically calculates the level of traditionality of exports through following formula:

$$
C_{i t}=\frac{\sum_{t 0}^{t} e_{t}^{i}}{\sum_{t}^{t j} e_{t}^{i}}
$$

Where

$C_{i t}$ cumulative export experience function of industry (i) in year ( $\mathrm{t}$ )

$t 0$ initial period, $\mathrm{t}$ is current time period and while $t j$ is the final time period

$e$ exports by industry (i) in time period ( $\mathrm{t}$ )

We have calculated Cit for Pakistan's top 35 export sectors at 2-digit SITC level at constant US\$ of 2010 for the period 1972 to 2015. These 35 sectors or industry constituted $99 \%$ of the total exports of Pakistan.

The value of the index ranges between 0 and 1 . A value close to 1 is considered as more traditional and close to 0 indicate non-traditional attribute. The mean value of the index is the average value of the traditionality for each industry. If graphs are plotted for index values it will start from a value close to zero and end up at value 1 at the final time period. In our case we will start from zero or close to zero in 1972 and end at 1 in the year 2015. The sectors are ranked according to ascending order of the mean value of the index. Lower value of index indicating non-traditional export sectors and as the index value increases the traditionality attribute also increases.

An industry which $C_{i t}$ value is high in the initial time period would be considered as traditional. If exports of product or sector are high at the initial period and smooth in the later years of the sample period, then it is regarded as a traditional item. Such graphs would be titled towards the left or upper diagonal of the graph area. While in the opposite case the product or sectors export would be considered as non-traditional.

Following Mejía (2011), we have set 0.4 traditionality index value as criteria for bifurcating industries as traditional and non-traditional. If mean value of and industry's Cit 
is greater than 0.4 that sector or industry will be considered as traditional and otherwise non-traditional. Table 4.6 shows only 10 sectors with Cit below 0.4 out of 35 sectors which constitute almost $20 \%$ of the total cumulative export value. This shows Pakistan's exports are mostly traditional. This shows country's exports diversification is very low. It is further confirmed from the values of standard deviation of the export experience function. Almost all products have the value around 0.3. Feed stuff has the minimum SD value, while its mean value is very high which is 0.74 showing a high traditional characteristic. On the other hand, Fertilizer manufactured has the highest SD value and also has a high mean value of 0.68 , which is showing a relatively high fluctuated traditional export sector.

Figure 2

Export Experience Function of top-6 export sectors

Export Experience Function of top-6 export sectors

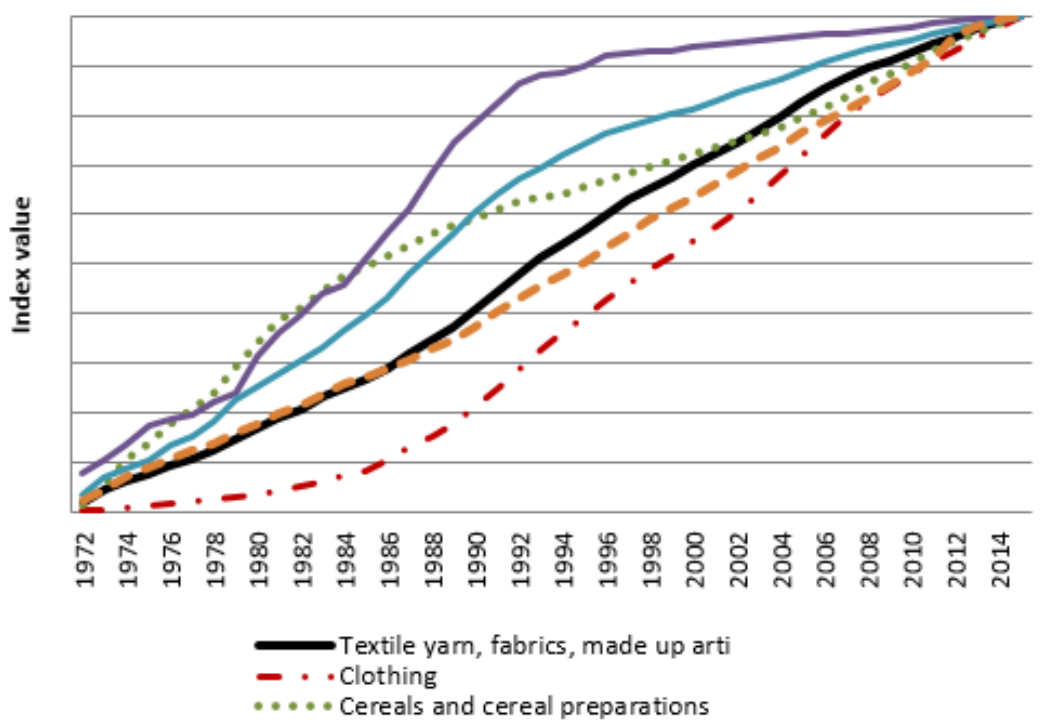

We have given graph of all the 35 items, which are ordered according to the value of exports. These graph further confirm their traditional feature.

Figure-2 shows almost all the products have traditional characteristics. Their mean index values are over 0.4. However, their concentration is in initial time period of the sample period. However, there is exception in that the mean value of Clothing is 0.395 which is very close to the value of 0.4 , but its share of exports is almost constant during most of the time of the sample period.

Almost the same trend can also be seen for the top exporting sectors, which rank as per descending order of cumulative export value is between 7 to 12 . 
Figure 3

Export experience function for next top-6 sectors

Export experience function for next top- 6 sectors

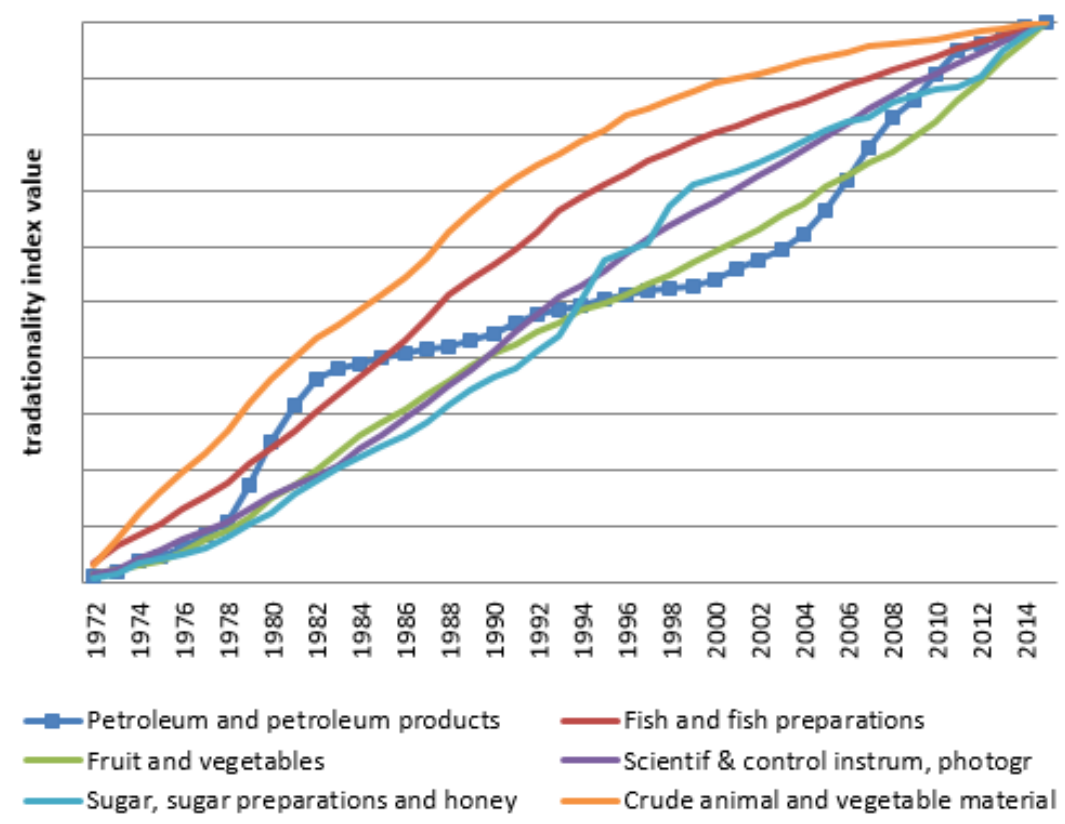

Figure 3 shows that almost every sector is concentrated on the left side of the graph which is an indication of traditional attribute. There the sectors, petroleum products, fruits \& vegetables, sugar, fish, scientific instruments and crude animal/vegetables materials are traditional items. Petroleum products have shown concentration on the left side in the initial period of the sample and further concentration is on the right side of the graph during the last half of the sample period. Mean value of the traditionality index is over 0.4 for all these products, which indicates that the sectors are of traditional nature.

Figure 4 shows the exports sectors, which in terms of value, ranked from 13 to 18 . Out of these 6 products 3 sectors namely, plastic materials, chemicals and non-metallic mineral sector are non-traditional. Their mean traditionality index value is lower than 0.4 and are concentrated on the right side of the graph. Coffee \& Spices sector is concentrated on left side while manufactures of metal and footwear are almost linear, which shows their traditional features.

Analysis of the rest of the 17 export sectors are given in the figure-5, which shows six export sectors had the non-traditional characteristics. These sectors are pharmaceutical, metal scrap, electrical machinery, animal vegetable oils, furniture and meat \& meat products. Rests of the products are traditional. 
Figure 4

Export experience function

\section{Export experience function}

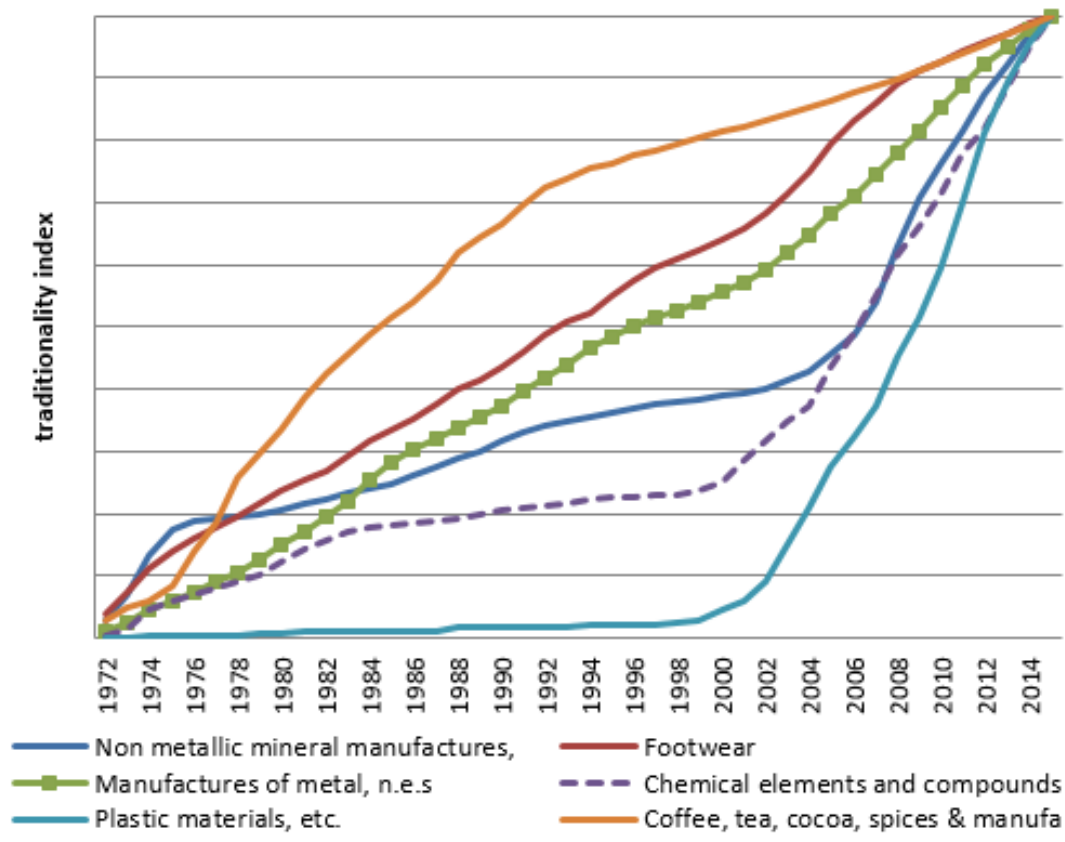

The analysis of the export experience function shows that only 10 products out of 35 are non-traditional that contributed only $20 \%$ in the total earning from countries merchandise exports in 2015. Therefore, it can be concluded that Pakistan's export structure is typically traditional. This implies a very low level of diversification of the exports.

We have used four different indices of export diversification. These indices are used by the majority of empirical researchers. All the above export diversification indices are concentration indices and lower values of these indices are indicating as diversification. Among all HHI is the only index which can be used to calculate both product as well as geographical export diversification. As far as the geographical export diversification is concerned, $\mathrm{HHI}$ is the index which is widely used by the researchers. The other three indices, UNCTAD - ED, DSD and TI are calculated by taking export of commodities only.

Almost every index showed the same result for export diversification level of Pakistan during our period of study. Although there are different magnitudes of the value of indices, however, the trend showed a very slow progress towards diversification. There was some period when negative progress towards diversification was observed. This trend may imply that there is no substantial change in the product export diversification over the last 44 years. If one compares HHI indexes for product and geographical diversification, it is revealed that geographical concentration is more than product concentration. 
Figure 5

Export experience function

\section{Export experience function}

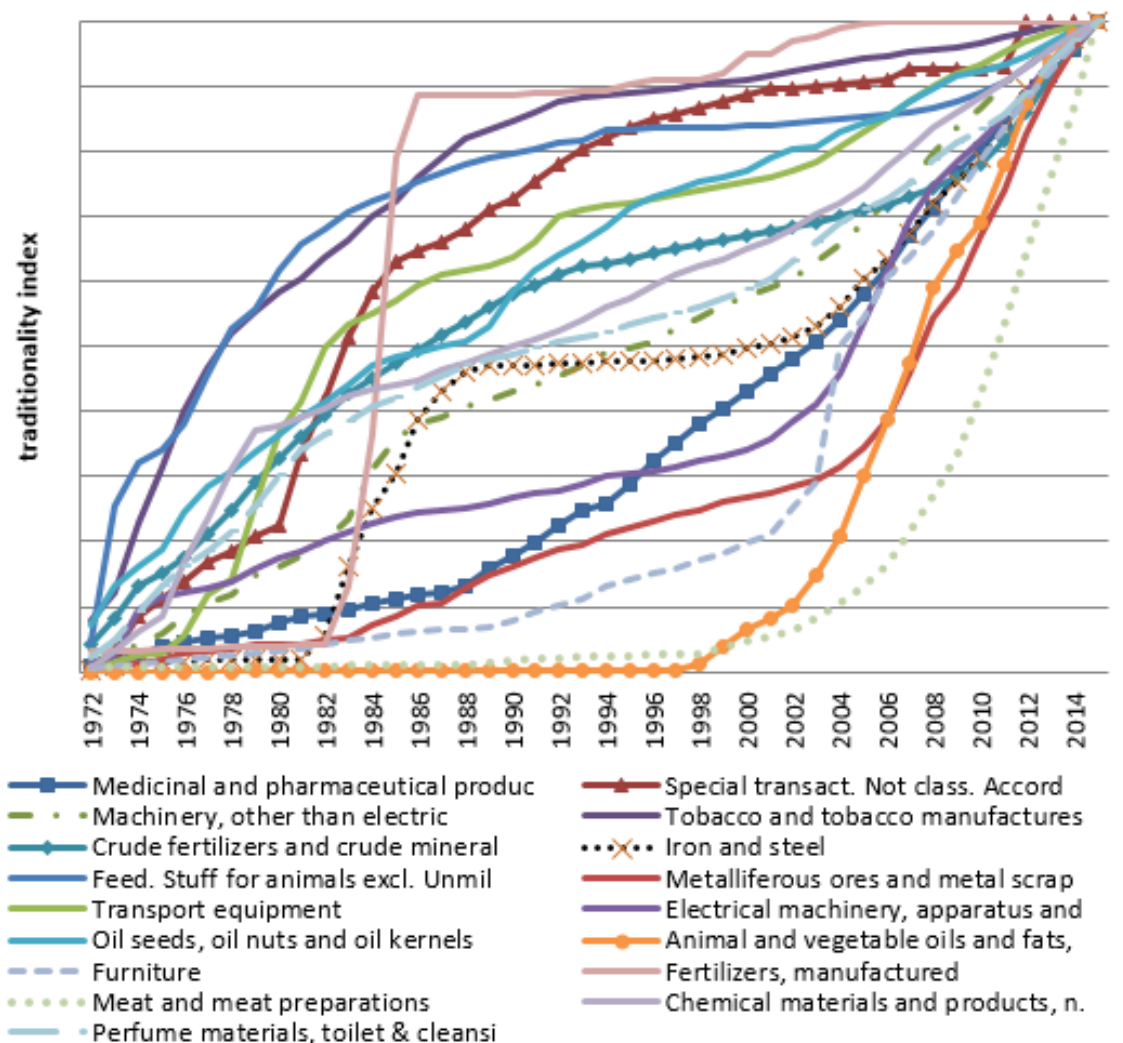

The analysis of export experience function is relatively different from that the other concentration indices. It shows the level of traditionality of exporting sectors. If a product or export sector analyzed as traditional sector, it means there is less diversification and vice versa. Our analysis showed traditionality attribute for the products export value of which is high. This shows that the result of the export experience function index is almost same as that of the other indexes.

Figure- 6 shows a direct or positive relationship between export diversification and GDP. The trend line is showing that as the GDP is increasing the diversification is also increasing and gradually it becomes somewhat flatter. While for geographical export diversification the curve looks almost linear, however after the point when GDP is at point 10.8 to 10.9. If we look at both curves a very small deviation can be seen from this point. Data shows that log of GDP at 10.8 was in the year 2000 from which import duty has been reduced to its minimum (of $25 \%$ ), and from this year import barriers are almost un- 
changed.

Figure 6

Relationship between Export Diversification and GDP
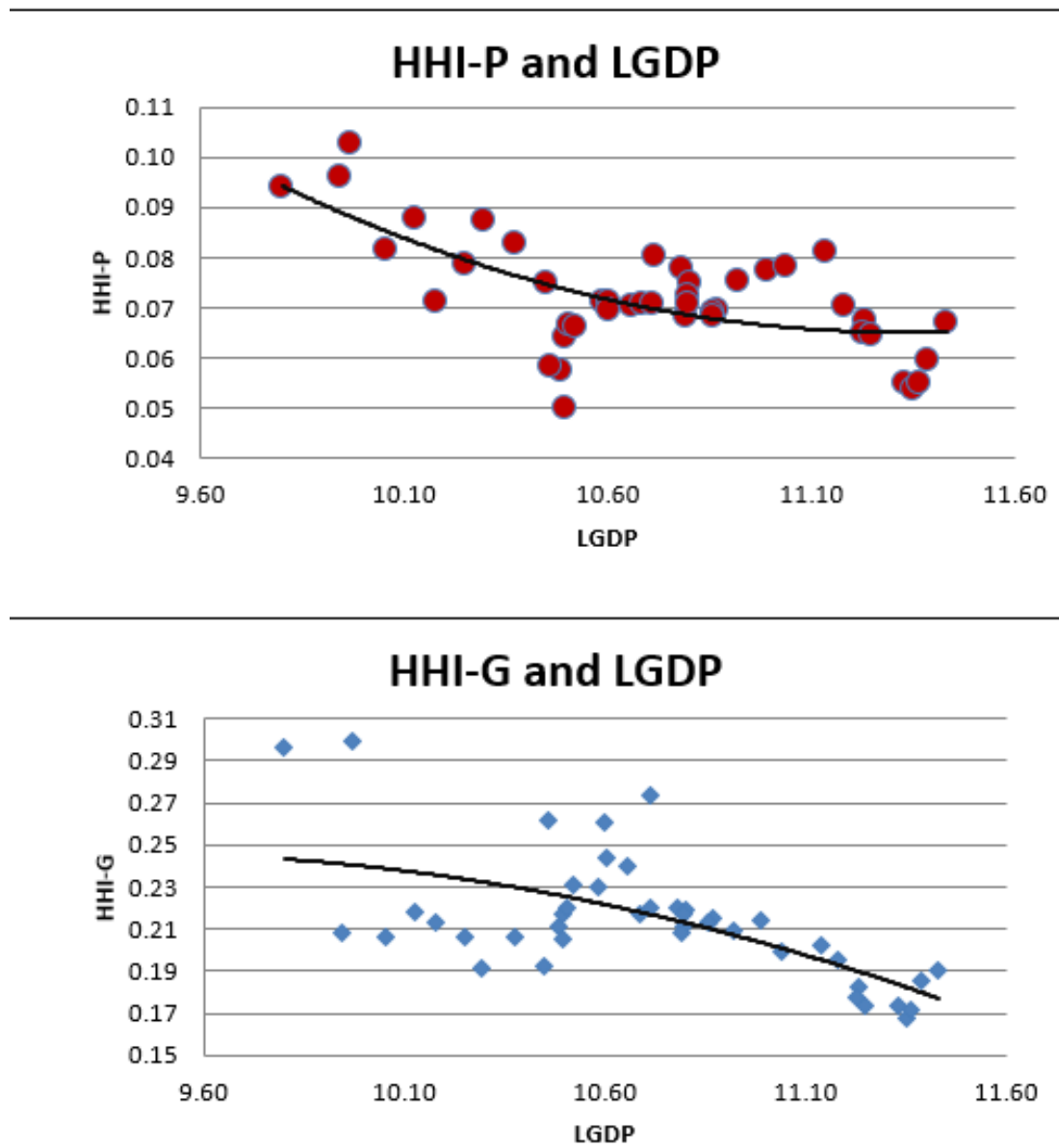

Ansari and Siddiqui (2017) have argued that the lack of export diversification is a key issue for unsustainable export growth of Pakistan. Their report advocated the adoption of a 'commodity vertical diversification strategy'. This means to focus on products at 6digist HS level within industry group specified at 4-digit or 2-digit HS level. Therefore, the policy must be focused upon the existing broad exporting commodity sectors which can be linked to other commodities under the sub heading at 6-digit HS level. The report also argued that horizontal export diversification (i.e. expanding existing product exports to new markets) is not an appropriate strategy for Pakistan and the government's emphasis on regional trade and signing FTA and PTA agreements does not deliver the desired 
results.

\section{Conclusion and Policy Recommendation}

Diversification of export is always the central point of the trade policies of the developing countries. Scholars have developed few indexes to measure the export diversification. We have calculated five indices and found that out of 5 indices 4 indices are concentration indexes and have shown similar trend for Pakistan. HHI is the index which can be used to measure both product and geographical concentration, while the rest of the 4 indexes are used to calculate product concentration only. Apart from these indices, UNCTAD also consider "number of export product (at 6-digit HS level) as an index of diversification and many researchers have also used them as proxies for export diversification. While reviewing our literature we found studies by Agosin, Alvarez, and Bravo-Ortega (2012); Ferreira and Harrison (2012), who have used number of product as proxy for export diversification.

While analyzing Pakistan's trade policies we have seen that there were relatively few policy measures to stimulate product diversification through the period 1972 to 2015. Our analysis showed that all the indices of diversification have no significant product export diversification trend. Policy measures have mainly emphasized on geographical export diversification through the holding of fairs \& exhibition, sending trade delegations, opening of office abroad or entering into trade agreements. However, the policy of encouraging geographical export diversification through preferential trade agreements has not given good results.

Since the 1990s all export policy statements have recognized the need for product export diversification to various extents and incentive for promotion of several non-traditional product lines have been provided but this has not produced the desired results. This is so primarily because the incentives provided - rebates, financial subsidies, import facilitation matching grants etc. - do not augment firm competitiveness in global markets. A firm specific policy incentivization strategy is an essential pre-requisite for effective product export diversification. The recent empirical literature has mostly suggested that diversification has a positive impact on economic development. We have found one study (Ferreira \& Harrison, 2012) which shows no impact of diversification on economic growth for Costa Rica. However, if countries are grouped as per their level of development, the findings showed relatively different results. It shows a positive relationship between economic growth and diversification for developing countries and positive relationship between growth and specialization (opposite of diversification) for developed countries. 


\section{References}

Agosin, M. R., Alvarez, R., \& Bravo-Ortega, C. (2012). Determinants of export diversification around the world: 1962-2000. The World Economy, 35(3), 295-315.

Ahmed, H., \& Hamid, N. (2014). Patterns of export diversification: Evidence from Pakistan. The Lahore Journal of Economics, 19, 307-326.

Akbar, M., Naqvi, Z. F., \& Iqbal, Z. (2001). External market conditions, competitiveness, diversification, and Pakistan's export performance. The Pakistan Development Review, 871-884.

Ansari, J., \& Siddiqui, A. (2017). Analysis of export growth 2010-2015 and policy suggestion. Trade Development Authority of Pakistan.

Balassa, B. (1965). Trade liberalisation and "revealed" comparative advantage 1. The Manchester School, 33(2), 99-123.

Balassa, B. (1977). 'revealed' comparative advantage revisited: An analysis of relative export shares of the industrial countries, 1953-1971. The Manchester School, 45(4), 327-344.

Ferreira, G. F., \& Harrison, R. (2012). From coffee beans to microchips: Export diversification and economic growth in Costa Rica. Journal of Agricultural and Applied Economics, 44(1379-2016-113686), 517-531.

Finger, J. M., \& Kreinin, M. E. (1979). A measure of export similarity'and its possible uses. The Economic Journal, 89(356), 905-912.

Forgha, N. G., Sama, M. C., \& Atangana, E. (2014). The effect of export diversification on economic growth in Cameroon. International Invention Journal of Arts and Social Sciences, 1(3), 54-69.

Hamed, K., Hadi, D., \& Hossein, K. (2014). Export diversification and economic growth in some selected developing countries. African Journal of Business Management, 8(17), 700-704.

Hamid, Z. (2010). Concentration of exports and patterns of trade: A time-series evidence of Malaysia. The Journal of Developing Areas, 255-270.

Hesse, H., et al. (2009). Export diversification and economic growth. Breaking into New Markets: Emerging Lessons for Export Diversification, 2009, 55-80.

Mejía, J. F. (2011). Export diversification and economic growth: An analysis of Colombia's export competitiveness in the European Union's market. Springer Science \& Business Media.

Persson, M. (2013). Trade facilitation and the extensive margin. The Journal of International Trade E Economic Development, 22(5), 658-693.

Siddiqui, A. H. (2018). Export diversification and growth in Pakistan: An empirical investigation from 1972 to 2015 1. Business and Economic Review, 10(1), 107-131. 